IZA DP No. 4517

Oppositional Identities and Employment for Ethnic Minorities: Evidence from England

Harminder Battu

Yves Zenou

October 2009 


\title{
Oppositional Identities and Employment for Ethnic Minorities: Evidence from England
}

\author{
Harminder Battu \\ University of Aberdeen
}

Yves Zenou

Stockholm University, IFN, CEPR and IZA

\section{Discussion Paper No. 4517 \\ October 2009}

\author{
IZA \\ P.O. Box 7240 \\ 53072 Bonn \\ Germany \\ Phone: +49-228-3894-0 \\ Fax: +49-228-3894-180 \\ E-mail: iza@iza.org
}

Any opinions expressed here are those of the author(s) and not those of IZA. Research published in this series may include views on policy, but the institute itself takes no institutional policy positions.

The Institute for the Study of Labor (IZA) in Bonn is a local and virtual international research center and a place of communication between science, politics and business. IZA is an independent nonprofit organization supported by Deutsche Post Foundation. The center is associated with the University of Bonn and offers a stimulating research environment through its international network, workshops and conferences, data service, project support, research visits and doctoral program. IZA engages in (i) original and internationally competitive research in all fields of labor economics, (ii) development of policy concepts, and (iii) dissemination of research results and concepts to the interested public.

IZA Discussion Papers often represent preliminary work and are circulated to encourage discussion. Citation of such a paper should account for its provisional character. A revised version may be available directly from the author. 
IZA Discussion Paper No. 4517

October 2009

\section{ABSTRACT \\ Oppositional Identities and Employment for Ethnic Minorities: Evidence from England ${ }^{*}$}

Where a community or group is socially excluded from a dominant group, some individuals of that group may identify with the dominant culture and others may reject that culture. The aim of this paper is to investigate this issue by empirically analyzing the potential trade-off for ethnic minorities between sticking to their own roots and labour market success. We find that the social environment of individuals and attachments to culture of origin has a strong association with identity choice. Our results also suggest that those non-whites who have preferences that accord with being "oppositional" do experience an employment penalty.

JEL Classification: J15

Keywords: ethnic minorities, identity, social networks, white's norm

Corresponding author:

Yves Zenou

Stockholm University

Department of Economics

10691 Stockholm

Sweden

E-mail: yves.zenou@ne.su.se

\footnotetext{
*We would like to thank Stephen Machin as well as two anonymous referees for helpful comments. We would also like to thank McDonald Mwale for his contribution to an earlier draft.
} 


\section{Introduction}

During the spring and early summer of 2001 there were a series of violent disturbances in various cities and towns in England (e.g. Oldham, Leeds, Burnley, Bradford), involving young British Asian men, young British White men and the police. As a consequence, a number of local and national enquiries were formed to investigate the causes of these disturbances. Though a range of potential explanations were proposed, two received considerable attention in political circles and also in the media. First, the lack of a shared civic identity to bring together diverse communities. Second, increasing segregation of communities on economic, geographic, racial and cultural lines.

The attention paid to these two factors is relatively novel in the UK and represents a departure from the long-standing debate in the UK which has tended to emphasize racial discrimination as the key force in driving ethnic disadvantage (CRE, 2002). The debate in the US, at both a policy and academic level, on these types of issues is of longer standing. One theme that has emerged from the academic literature is that some individuals in ethnic groups may "choose" to adopt what are termed "oppositional" identities. ${ }^{1}$ Where a community or group is socially excluded from a dominant group, some individuals of that group may identify with the dominant culture and others may reject that culture. ${ }^{2}$ This may occur even if the latter groups preferences involve a lower economic return. From the standpoint of those who choose not to take a rejectionist stance the rejectionists are making poor economic decisions; they are engaging in self-destructive behaviour. Such preferences may stem from a lack of economic opportunity, discrimination or it may stem from a desire to display greater racial or religious solidarity (Akerlof and Kranton, 2000; Selod and Zenou, 2006). ${ }^{3}$

In the economics literature there is little direct evidence on what drives such behaviour and on the implications of such behaviour for labour market outcomes. Blackaby et al. (1997) for the UK have argued that the labour market disadvantage of ethnic groups may stem from what they describe as "the cultural outlook of the minority group itself". They go further and argue that some groups may have "a taste for isolation" which limits their economic opportunities and raises their unemployment rates. The authors do not, however, conduct any formal empirical analysis to gauge the importance of these effects. Similarly Berthoud (2000) acknowledges the importance of

\footnotetext{
${ }^{1}$ Our use of the term ethnic refers to non-white identities, although we acknowledge that whites also have an ethnicity.

${ }^{2}$ An alternative explanation revolves around qualifications: skilled minorities could benefit more from integration than unskilled minorities (Cutler and Glaeser, 1997).

${ }^{3}$ The difficulties in negotiating two cultures has long been a theme in the arts. Recent explorations include the motion pictures "East is East", "Bend It Like Beckham", "Ae Fond Kiss" and "My Son the Fanatic" and within literature Hai (2008).
} 
identity- related factors in his discussion of the alienation of certain groups, which he argues is a consequence and a reinforcing cause of their exclusion from employment. Brown (2000) makes a similar argument when he argues that quantitative work has been constrained by a general failure to collect "cultural" information. There is a tendency then to use ethnic group membership as a catch-all measure for cultural differences.

This paper undertakes a simple empirical investigation of the relationship between ethnic identity and employment in the labour market. We have at our disposal a unique data set for Britain, which deliberately over-samples ethnic groups and contains extensive information on various issues surrounding ethnic identity and preferences. This allows us to say something on the factors that might lead some to adopt or possess an oppositional identity and ascertain whether such preferences are associated with an employment penalty. Our results indicate that the social environment of individuals has an influence on their identity choice and that those non-whites who have preferences that accord with being oppositional are likely to experience an employment penalty.

The remainder of the paper has the following structure. In the next section, we summarise the existing literature in this area. In section 3, our data set is described and we provide some descriptive statistics. Section 4 deals with the measurement of ethnic preferences. Section 5 presents the empirical results. The final section offers a summary and discussion.

\section{A Summary of the Literature}

What is ethnic identity? According to Akerlof and Kranton (2000), identity is a person's sense of self or self image and "his or her identity is bound to social categories; and individuals identify with people in some categories and differentiate themselves from those in others." (page 720). In other words, identity is associated with the social environment and expected respective behaviours (a prescription or norm for behaviour). Deviations from the prescription generate disutility. Examples of social categories include racial and ethnic designations and ethnic identity is then the extent to which members of a particular ethnic group associate themselves with their ethnic background or culture.

The extent to which this occurs is personal and can be based on a whole host of connected factors including geography and the neighborhood in which individuals live, family background and peer pressure, time of arrival in a country, language and a desire to socially interact in one's own language, the level of human capital, a lack of economic opportunity, discrimination and expectations of unfavorable treatment and rejection by whites, prejudice against whites, and a desire to share culture, display greater racial or religious solidarity and improve access to 'ethnic goods' such as food, education or religious services (Akerlof and Kranton, 2000; Ihlanfeldt and 
Scafidi, 2002).

Few theoretical models have investigated what drives ethnic preferences and the link between ethnic preferences and outcomes. Akerlof (1997) argues, supported via evidence from sociology and anthropology, that concerns for status and conformity are key drivers of individual outcomes including educational attainment, law breaking behaviour and childbearing. Akerlof and Kranton (2002) propose a theory in which a student's primary motivation is his or her identity (i.e. students, have to choose their social categories and effort in school), students have an interest to minimise the distance between themselves, their "proper" characteristics and actions and the self-image associated to the specific category and the quality of a school depends on how students fit in a school's social setting. Austen-Smith and Fryer (2005) model peer pressures in education by putting forward the tension faced by individuals between signalling their type to the outside labour market and signalling their type to their peers: signals that induce high wages can be signals that induce peer rejection. One of their main results is to show that the more individuals discount the future, the more acute peer pressure becomes and the more homogenous groups are (in terms of education).$^{4}$

Bisin et al. (2008a) construct a model of ethnic identity formation focusing on how choice of identity is affected by cultural transmission and socialization within the family, peer effects and social interactions. Battu et al. (2007) develop a model which has some of these features. Here nonwhite individuals are defined with respect to their social environment (family, friends, neighbors) and their attachments to their culture of origin (religion, language). Jobs are mainly found through social networks. ${ }^{5}$ Non-whites must decide to totally or partially adopt the white's culture or to reject it by anticipating the implications of this choice on their labour market outcomes. Interacting with whites is beneficial since non-white workers may benefit from the high quality of whites' social networks since the latter do not face discrimination. There is an externality of being "close" to whites. This externality causes the employment rate of non-whites to be positively affected by the employment rate of whites. However, depending on the willingness to interact with whites or to

\footnotetext{
${ }^{4}$ Other related literatures emphasise the importance of English language fluency (Chiswick, 1978; McManus et al. 1983; Borjas, 1994; Dustmann and Fabbri, 2003) and religion and culture (Iannaccone, 1998; Lazear, 1999; Brown, 2000) for the degree of assimilation and labor market outcomes of immigrants. Lazear (1999) focuses on cultural differences (religion is obviously part of the culture of people) between the minority and the majority group and shows that individuals from minority groups are more likely to adopt the culture of the majority when the minority group accounts for a small proportion of the total population.

${ }^{5}$ Other studies have also emphaised social networks. In particular, when the unemployment rate is high among a particular group, individuals of that group have few connections that can refer them to jobs and their social network is poor (Calvó-Armengol and Jackson, 2004; Calvó-Armengol and Zenou, 2005; Montgomery, 1991; Topa, 2001; Ioannides and Loury, 2004; Zenou, 2009).
} 
adopt the white's culture, non-whites can benefit more or less from whites' connections to jobs. They find that totally identical individuals can end up with totally different choices. Some nonwhites will totally reject the white's culture even though they know that it will sharply decrease their chance of being employed. This is partly because information about jobs can only be acquired through social networks (employed friends). In this respect, oppositionalists do not want to interact with whites and "pay" in some sense the price of this behaviour by experiencing high unemployment rates and a low probability to find a job compared to the other non-whites that are more willing to adopt the white's norm.

There are a small number of empirical studies examining the connections between identity and outcomes and most of this research tends to be in the field of education and focuses on the academic achievement of African American youths. Here it is argued that African American students in poor areas may be ambivalent about learning standard English, where this may be regarded as "acting white" and adopting mainstream identities (Ogbu, 1978; Fordham and Ogbu, 1986; Delpit, 1995; Ainsworth-Darnell and Downey, 1998; Austen-Smith and Fryer, 2005). When the distance to the white community increases, utility increases, reflecting the disutility of interracial contacts with white "neighbors". This is the case because some non-whites may not "trust" people from other communities, especially whites, especially when they have been historically discriminated against (see Alesina and La Ferrara, 2002, for an interesting study on trust and racial mixing). What matters is to "fit in" and not to disappoint your peers. Otherwise you are pilloried. However, much of the quantitative research suggests that "acting white" is a myth (Ainsworth-Darnell and Downey, 1998 and Cook and Ludwig, 1998 ) although a more recent study by Fryer and Torelli (2005) finds some support. ${ }^{6}$

A very small number of studies gauge the labour market consequences. Pendakur and Pendakur (2005), using data from Canada, examine the effects of ethnic identity on the use of informal networks to obtain jobs and on employment itself. They find that for European ethnic minorities the strength of minority identity is positively related to the use of informal methods (friends and family) for gaining employment but there is no effect for "visible" ethnic minorities (those of nonEuropean and non-Aboriginal origin). For "visible minorities", ethnic identity is also associated with lower occupational prestige and this finding is not evident for white minorities. Mason (2004) focuses on the consequences of identification to the majority culture and skin color of Hispanic Americans for labour market outcomes. For Hispanic groups, adopting a non-Hispanic white racial identity is associated with higher annual income and hourly wages. However, this is not sufficient to overcome the negative penalties associated with a dark complexion or a non-European

\footnotetext{
${ }^{6}$ Patacchini and Zenou (2006) also examine this relationship.
} 
phenotype. Bisin et al. (2008b) finds that the main determinants for ethnic identity in the UK, especially for Muslims, are experiences of racial harassment, language spoken at home and with friends, quality of housing and family structure. They do not, however, examine the labour market consequences of identity formation.

A couple of recent empirical studies have argued for a broader conceptualisation of identity. Constant and Zimmerman (2008) study the ethnic self-identification of migrants in Germany alongside their identification with the German majority culture. They construct a measure of ethnic identity using information on language, culture, societal interaction, history of migration, and ethnic selfidentification. They use this to classify migrants into four groups: integration (identify with both cultures), assimilation (identify with host and not origin), separation (identify with origin and not host) and marginalization (identify with neither host or origin). Their results indicate that both integrated and assimilated men have a higher probability of working and increased earnings whilst separated and marginalized men have lower employment probabilities and lower earnings compared to assimilated men

Nekby and Rödin (2007) examines identity formation and the consequences of identity formation for labour market outcomes for a cohort of students with immigrant backgrounds in Sweden. Identity strength is measured via the strength of identity to the (ethnic) minority and to the (Swedish) majority culture. Their results indicate that what matters for incomes and employment is the strength of identification with the majority culture irrespective of the strength of ethnic minority identity. Nevertheless, males with a strong sense of their ethnic identity but at the same time a weak tie to the majority culture (the separated) are found to have a lower probability of employment compared to the assimilated (adherence to majority culture and weak ties to own culture). The direction of causality is though unclear. Does a strong host country identity increase the probability of employment or does success in the labour market increase identification with the host country?

\section{Data and Descriptive Statistics}

The data we employ is derived from the Fourth National Survey of Ethnic Minorities (FNSEM) collected in 1993/94 by the Policy Studies Institute. This includes a standard set of variables capturing individual, demographic and job characteristics (see Modood et al., 1997 for details). It has the advantage that it over-samples ethnic minority groups and explicitly acknowledges the heterogeneity within the non-white population where the ethnic population is composed of six groups (Caribbean, Indian, Pakistani, African-Asian, Bangladeshi, and Chinese).$^{7}$ At the heart of the

\footnotetext{
${ }^{7}$ For historical reasons Black Africans were not included. Furthermore, the survey only covers England and Wales.
} 
data set is the 1991 Census. This was used to select the sample of ethnic minorities included in the survey. In particular, all electoral wards in England and Wales were divided into three bands (high, medium and low) according to the proportion of the population who were members of ethnic minorities. ${ }^{8}$ Within each band a sample of wards was chosen and within each of these selected wards a sample of addresses was picked. Interviewers then visited 130,000 addresses to identify any members of the target minority groups living there who could then be interviewed. At each household containing adults from ethnic groups, one or two were selected for interview. Where a household had more than two eligible adults, two were chosen at random. Two questionnaires were randomly assigned to the two adults selected. Though both questionnaires had the same core set of questions they did contain a different set of secondary questions. Importantly, a majority of selected individuals were interviewed by a member of their own ethnic group either in English or in their own language, thereby maximizing the response rate and reducing any potential source of bias. Interviews were successfully obtained in 3291 ethnic households with 5196 ethnic individuals. A comparison sample containing white households was also obtained generating 2867 white interviews. ${ }^{9}$ Means and standard deviations for a range of variables for the ethnic sample are given in Table 1.

\section{[Insert Table 1]}

The dataset is unique in that it contains extensive information on various aspects of an individual's ethnic identity and preferences. ${ }^{10}$ In particular, we can place individuals in social space via a number of questions on identification with Britishness, identification with their own ethnic group, attitudes towards inter-marriage and preferences in terms of the ethnic makeup of their own child's school. There are though a number of caveats in interpreting cultural information There is the usual issue of the reliability of individual responses and also how responses to different questions may consign the same individual on quite different positions in social space relative to whites. Different questions may also indicate the possession of plural identities whereby individuals belong to more than one group or community. An individuals ethnic background may simply be one of the many identities that individuals have where different identities may be invoked in particular contexts. Identities in a sense can be chosen even when the choices are constrained and the constraints vary in strength depending on the circumstances (Sen, 2000). Furthermore, some questions may

\footnotetext{
${ }^{8}$ Electoral wards have been described as the geographic building blocks of the UK. There are 9,527 wards in England and Wales.

${ }^{9}$ The response rates were $61 \%$ for Caribbeans, $74 \%$ for Indians and African Asians, $73 \%$ for Pakistanis, $83 \%$ for Bangladeshis, $66 \%$ for Chinese and $71 \%$ for Whites.

${ }^{10}$ Though the survey dates back to 1984, the data is the best available in terms of containing extensive information on ethnic identity preferences. The nearest equivalent is the UK Longitudinal Study, Understanding Society, but that will only be released during 2010 .
} 
not be wholly reliable in terms of locating an individual in social space. For example, it is debatable whether information on the importance of religion to ones life and also whether an individual wears ethnic or religious clothing can tell us about the degree of opposition to mainstream values (i.e. the wearing of a turban by a Sikh does not necessarily equate with being oppositional).

In the FNSEM the importance of ethnic identification was captured by reading out two statements to interviewees: 1. In many ways, I think of myself as being British. 2. In many ways, I think of myself as [respondent's ethnic group]. Respondents were asked if they agreed or disagreed and if so, whether strongly or just a little. Table 2 and 3 summarize the responses across different ethnic groups. Both questions are essentially asking about identification with a country, with a place and its way of living and the responses do reveal the difficulty in clearly assigning our ethnic groups to different locations within social space. ${ }^{11}$ Leaving aside the Chinese for a moment, it is clear that just over $55 \%$ of the remaining ethnic groups agreed that they thought of themselves as British. The group that agreed the most are the African-Asians (71\%) and the group that agreed the least are the Bangladeshis (56\%). The Caribbeans are the most likely to disagree (34\%). Other evidence from this data set and not presented here reveals that around a quarter of British-born Caribbeans did not think of themselves as being British. This contrasts with the West Indian migrants of the 1940s and 1950s who by most accounts thought of themselves as British and often talked of coming to "the mother country" (Modood et al. 1997). The Chinese in Table 1 stand out since roughly equal percentages agreed and disagreed with the notion of being British (44 and $41 \%$ respectively). At least in terms of this question the Chinese seem to sit at both extremes in terms of their location in social space.

[Insert Tables 2 and 3 here]

Table 3 confirms that there is a strong sense of ethnic identity amongst minority groups. Over $80 \%$ of each group either agreed strongly or agreed that they thought of themselves in terms of their own ethnic group. The figures for those who disagreed are quite small - the highest is for Caribbeans with around $10 \%$ of them not thinking of themselves as Caribbean. Therefore, whilst a significant minority disagree with the notion of being British, this is not the case when it comes to their own ethnic identity. Furthermore, the answers to the two questions reveal that there may not be a conflict in identities. For example, being British and being Bangladeshi does not compete in the minds of most respondents, suggesting that identities can indeed be multiple (Sen, 2000). Table 4 provides some data on another dimension of identity, namely marriage and in particular attitudes to inter-marriage. Inter-marriage is considered to be a measure of social assimilation and also a factor producing it (Pagnini and Morgan, 1990). On the other hand some ethnic and

\footnotetext{
${ }^{11}$ Note that it does not follow that a failure to feel British equates with antagonism towards whites.
} 
religious groups regard inter-ethnic marriage as a potential threat endangering and undermining ethnic identities. In the FNSEM individuals were asked "If a close relative were to marry a white person would you not mind, would you mind a little, would you mind very much?" Here significant percentages of the three South-Asian groups said they would mind very much with the greatest hostility being among the Pakistani population (37\% of them say they would mind very much a mixed marriage). A majority of the other groups said that they would not mind and amongst Caribbeans (8\%), African Asians (13\%) and the Chinese (7\%) the percentages that would mind very much are quite small. ${ }^{12}$

\section{[Insert Table 4 here]}

Tables 5 and 6 relate to an important area of controversy in both the UK and US; the role of schools in keeping different ethnic communities separate from one another. In one UK report it was argued that schools dominated by one race or faith should offer at least a quarter of their places to pupils from other backgrounds (Building Cohesive Communities, 2001). On the other hand, the UK government is committed to the expansion of church and faith-sponsored schools. A number of questions were asked in the FNSEM to assess the relevance of ethnicity in influencing the kind of school that people wanted for their children. First, how important is ethnicity in choosing a school (Table 5)? Second, what proportion of one's ethnic group would you like in your children's school (Table 6)? In Table 5 the most common answer is that it would have no influence. In fact, it was deemed an important consideration for only a quarter of African-Asians and Indians and for around one third of Caribbean's and Bangladeshis. Only one in ten Chinese thought it important. Table 6 gives some data on the preferred proportion of one's ethnic group in a school. Of those who did have a preference $40 \%$ of Caribbeans and $38 \%$ of Pakistanis wanted a school with $50 \%$ or more from their own ethnic group. For the African Asians, Indian, Bangladeshi and Chinese groups the figures are much smaller $(24 \%, 22 \%, 29 \%$ and $11 \%$ respectively).

[Insert Tables 5 and 6 here]

\section{Measurement and Estimation}

Our empirical strategy is in two stages. First, by focusing on our ethnic groups, we will try to decipher the types of factors that are connected to the strength of identity for non-whites. Second,

\footnotetext{
${ }^{12}$ Hostility to inter-marriage may not always be a signal of an oppositional identity. For example, if one believes in assimilation but also believe that society is prejudiced against inter-racial partnerships (or the children of such partnerships) one may be hostile to a close relative marrying outwith ones own community but still in favour of mainstream culture.
} 
we will try and gauge the relationship between identity strength and the probability of being employed.

The strength of identity is captured in two ways where these form our dependent variables in a set of probit estimations. First, a binary dependent variable for each of our identity related questions discussed in the previous section. In particular, the extreme values of each of the variables are coded one and are taken to encapsulate an oppositional identity and all other responses are coded zero. For example, if an individual strongly disagrees with inter-marriage that is coded one and zero if not (Smind). Full details of the identity variables are given in Table 7. Second, we take the responses from the four variables in Table 7 (Nbrit, Oethnic, Smind and Schcon) and aggregate them. If an individual gives an extreme response for at least two of the four questions, then he/she is considered as oppositional and the aggregate variable is coded one and zero otherwise (Opid). On this basis, less than $10 \%(8.67 \%)$ of individuals in the sample are deemed oppositional.

\section{[Insert Table 7 here]}

We also need variables that define the social environment of each individual and his or her attachment to their culture of origin. Language, or more exactly fluency in English captures some aspects of the social environment and clearly a lack of English language fluency reduces the probability of contacts with whites. Similar arguments hold for place of birth and years since arrival in the UK; being born and raised abroad obviously implies that individuals have had fewer contacts with the majority population. We thus construct a dummy capturing language fluency (Fluent), a born in the UK dummy (UKborn), and a variable that indicate the number of years since arrival in the UK (Yrsmg). We have also two dummy variables concerning marriage: married to someone from own ethnic group (Marown) and married to someone from another ethnic group (Intmar). Being married to someone from another ethnic group may indicate greater assimilation and be seen as a step up the white social ladder. Finally, since neighbors do impact on identity choices, we construct a dummy variable that indicates if the individual resides in an area where more than $33 \%$ of people of the same ethnic group live (Oethcon). In particular, some minorities may choose to live within their communities in order to gain access to ethnic shops, places of worship, display greater racial or religious solidarity or in order to socially interact in ones own language. Residence in ethnic enclaves potentially reduces contacts with whites.

To gauge the effects upon employment, we estimate a set of employment equations using probit estimation. Employment is coded unity and zero otherwise using the ILO definition. We do not examine the effects on earnings, since the response rate for earnings in the FNSEM was poor especially for the South Asian groups. In any case, it could be argued that the most important dimension of economic disadvantage is employment and not earnings. According to Blackaby et 
al. (1997), "the lack of jobs is a major factor of the discriminatory process and may ultimately be more socially damaging".

One obvious problem here is that the strength of an individual's identity may in fact be endogenous. ${ }^{13}$ A lack of success in the labour market may induce or encourage some to adopt identities that are out of kilter with mainstream or "majority" values. Dealing with this issue especially in a cross-sectional context is difficult. One standard approach is to undertake a two-stage instrumental variable estimation, where in the first stage we estimate a set of identity probit equations with appropriate instruments. In the second stage, we insert the predicted values into the employment probit. The preference's equation is identified with a set of appropriate instruments that capture the influence of prior experiences or preferences. The instruments include whether individuals have experienced racial harassment (Rharra), if their parents made the decision in choosing their wife or husband (Arrmar) and if they prefer a school of their own religion for their children (Schrelig).

For these to be suitable instruments, they must not affect the probability of being in employment other than through the effects of these variables on the probability of having an oppositional identity. Indeed, using a likelihood ratio test, we were able to accept the null hypothesis that the instruments either individually or jointly do not have a direct impact on the probability of employment. Furthermore, the instruments must not be determined either by identity choice or employment outcomes (the instruments must avoid the possibility of reverse causality). This is no simple task. Take parental influence on marriage. Being in employment may make it easier for parents to find you a match. On the other hand, being employed by non-ethnic employers may raise contacts with whites and by raising the chances of procuring a white mate reduces the probability of an arranged and mono-ethnic marriage. In terms of single faith schools the act of a parent selecting one's partner is clearly beyond the individuals control. However, the act of accepting a parent's choice is not. And those individuals whose acceptance of parental authority and traditional values extend this far may well be less employable. One then needs to take care in interpreting our results and perhaps cautious in making strong claims of causality. The results that we report, be they two stage instrumental estimation or otherwise are simply an indication of the relationship between identity choices and employment but by no means the final word.

Throughout our estimations the sample utilized is the working age population of males (aged 16 to 64 ) and females (aged 16-59). Given their very small numbers in the dataset the Chinese are excluded from the analysis and the Bangladeshi and Pakistani group are combined on the basis that they are both overwhelmingly Muslim, they face similar levels of relative disadvantage in the labour market (Blackaby et al. 1999) and they emanate from rural areas in their origin country.

\footnotetext{
${ }^{13}$ Using the Smith-Blundell test of exogeneity (Smith and Blundell, 1986) we found that three of our identity measures were endogenous (Nbrit, Smind and Schcon).
} 
All results reported are marginal effects.

\section{Empirical Results}

\subsection{Identity formation}

The results in Table 8 focus on the correlation between identity and other factors. Separate estimations are undertaken for each of the identity terms and the aggregate identity variable (Opid). All three instruments behave as expected and are jointly statistically significant at all conventional levels of significance (see likelihood ratio tests at bottom of Table 8). Whilst having experienced racial harassment (Rharra) leads individuals belonging to an ethnic group to strongly reject British culture and all that is associated with it (interracial marriage, school mixing, etc.), it does not seem to strengthen their sense of belonging to their own ethnic group (Rharra has a significant effect on all identity variables but Oethnic). On the other hand, those who prefer a school of their own religion (Schrelig) are consistently more likely to be oppositional across all five estimations. Having experienced an arranged marriage (Arrmar) is positively related to an oppositional stance in three cases (Nbrit, Smind and Opid) with the strongest effect being evident for Smind: those who have had an arranged marriage are more likely to strongly mind inter-marriages.

\section{[Insert Table 8 here]}

Attachments to the culture of origin (language, religion,) and social environment (family, friends, neighbors) are key factors here. In Table 8, it is easy to see that language fluency and identity are connected. In particular, we find that being fluent in English indicates less of an oppositional identity in four out of five identity regressions. Language fluency tends to be associated with "mainstream" values. The two other variables that are closely related to language fluency (UK born and years since arrival in the UK) are also significant and with the expected signs. Being UK born is associated with a less oppositional stance for three of the identity variables (Nbrit, Oethnic and Opid). As one would expect the longer an individual has been in the UK (Yrsmg), the less hostile they are to being British (Nbrit) and the less they emphasize their own ethnic group (Oethnic). The ethnic enclave's variable (Oethcon) is also significant and has the expected sign. In particular, living in a high ethnic concentration area (over a third of the population in your area is from your own ethnic group) makes it more likely that individuals will strongly disagree with being British (Nbrit) and raises the probability that individuals strongly align themselves with their own ethnic group (Oethnic). Being married to someone from another ethnic group (Intmar) suggests that individuals choose to adopt the white's norm and, in particular, to strongly agree with being British. 
The dummies for ethnic groups reveal that the African-Asians are the least oppositional relative to the omitted category of Indians. They are less likely to strongly disagree with being British, are less likely to align themselves strongly with their own ethnic group and are less likely to strongly disagree with inter-marriages. The other groups are more difficult to characterize in this manner. The Bangladeshi/Pakistani ethnic group display oppositional identities on only one dimension (Schcon) and the Caribbean group displays oppositional identities on just two dimensions (Nbrit and Schcon). The finding that Caribbeans are less likely to see themselves as British (the coefficient on Nbrit is positive and statistically significant) contrasts with the many Caribbeans who migrated to the UK in the 1940s and 1950s and who by many accounts did regard themselves as British and often spoke of coming to the "mother-country" (Modood et al., 1997). In terms of minding inter-marriages Caribbeans are less likely to be hostile. This is unsurprising since half of the live in partners of British born Caribbean men were white females (Modood et al., 1997). Being married to a white female may then be an indicator of assimilation and could be seen as a step up the white social ladder and so be related to career aspirations (Berthoud, 2000, and Meng and Gregory, 2005). This is supported by our dummy for inter-marriage (Intmar), which is associated with less hostility to inter-marriages and the notion of being British.

\subsection{Identity and the probability of employment}

The results from our instrumental variable employment probits are given in Table 9 (second stage). As stated earlier, the identity terms capture to some extent the willingness of non-whites to interact with whites. The question then is whether there is a negative externality from not associating with the majority group in term of a loss in employment. This is indeed what is found but for only two out of four of the identity terms. Non-whites who strongly disagree with the notion of being British are less likely to be employed (by around 7\%). This compares with a penalty of around $11 \%$ where we do not correct for the endogeneity of identity (not reported here). However, having an identity that is closely tied to ones ethnic group does not seem to generate an employment penalty (Oethnic). There is also a cost associated with being very hostile to inter-marriages; those who strongly disagree with inter-marriages incur an employment probability penalty of around 6.5\%. For our aggregate measure, Opid, we find that having an oppositional identity does reduce the probability of being in employment by around $6 \%$. This compares with $9 \%$ where we do not correct for the endogeneity of ethnic preferences (again not reported here).

\section{[Insert Table 9 here]}

Let us now focus on the other variables that influence the social environment of individuals. There is evidence of a linguistic advantage for those who are fluent in English in terms of employment. This 
accords with other research that finds that ethnic group differences in communication styles have an important influence on the labour market success of low-income non-whites in the US (McManus et al., 1983; Lang, 1986; Cornell and Welch, 1996; Lazear, 1999). The positive relationship between language fluency and employment perhaps reflects improved job search strategies, an ability to convince potential employers of the value of their qualifications or the possibility that for certain jobs (e.g. in the service sector) fluency is an entry requirement (Dustmann and Fabbri, 2003). It is also found that the longer have non-whites been in the UK, the more likely they are to work. Being resident in an ethnic enclave only matters in regression (1) where the identity term is Nbrit: here living in an ethnically concentrated neighborhood reduces the probability of being in employment and whilst this is consistent with other studies on ethnic enclaves (see, in particular, Edin et al. 2003) our ethnic concentration measure is narrow and potentially endogenous (those with high oppositional preferences may select into neighborhoods with higher same group concentrations).

A clear benefit arising from inter-ethnic marriage is evident. In three of the regressions being married either within ones own group or outside is associated with a higher probability of being in employment relative to being single (the omitted category) and the effect is larger for those who marry outwith their own community (20\% as opposed to 13-15\%). For the ethnic dummies we find that Bangladeshis and Pakistanis, who are both overwhelmingly Muslim, are less likely to be employed relative to Indians (the omitted category) across all regressions and this effect is strong at approximately 24\%. The coefficients on age, age-squared and children behave as expected and since there is no discernible effect arising through gender, separate estimates for males and females are not attempted. The effects of gender on employment may vary across our ethnic groups and in separate estimations for each ethnic group we did find that Black Caribbean males were less likely to be in employment. The presence of children reduces the probability of employment where this may stem from the disincentive effects arising through the benefit system that links benefits to family size. There may be differential effects here across gender. It has been suggested that one mechanism for overcoming disadvantage is to improve educational qualifications (Leslie and Drinkwater, 1999). Though little is happening with respect to foreign qualifications, possessing a UK degree does seem to matter. Having a UK degree raises the probability of being employed of ethnic groups in the UK by up to $25 \%$. The lack of any effect for foreign qualifications (Fqual) may reflect some doubt amongst native employers about the quality and portability of foreign qualifications (Friedberg, 2000).

Strong spatial effects are apparent when examining home (Owner-occupier) and vehicle (Own car) ownership. Having access to a private vehicle opens up the potential area of job search and improves the possibility of getting employment (Thomas, 1998; Raphael and Stoll, 2001; Patacchini and Zenou, 2005). Other evidence reveals that ethnic groups in the UK are more likely to use 
public transport relative to whites with non-whites and Bangladeshis in particular, having the lowest car ownership (Owen and Green, 2000). The importance of household tenure in predicting unemployment is well established (Hughes and McCormick, 1987) and owner-occupier rates have been found to be higher for Indians relative to whites with non-white Caribbeans and Bangladeshis more likely to be renting from the social landlord sector than the private sector (DETR, 2000). ${ }^{14}$ We find that those individuals who are owner-occupiers and those who own their own car are more likely to be in employment. The local economic environment may also determine the employment position of minorities and this is captured via a set of ward level unemployment dummies. However, there is no evidence that higher local unemployment results in a lower probability of obtaining employment. ${ }^{15}$

\section{Conclusions}

The argument that individuals possess or display oppositional identities has been an important theme in attempting to explain racial differences in school performance in the US (Ogbu, 1978; Fordham and Ogbu, 1986; Ainsworth-Darnell and Downey, 1998). However, the relationship between ethnic identities and the labour market remains relatively unexplored at both a theoretical and empirical level. In terms of the latter, data availability seems the key constraint. This paper examines the relationship between ethnic identity and employment in the British labour market using a dataset which is rich in information on ethnic identity and preferences.

Our findings do indicate considerable heterogeneity in the non-white population in terms of preferences. Though the African-Asian ethnic group is found to have less extreme oppositional preferences, the other groups are much more difficult to characterize in this manner, since there are differences depending on how one measures ethnic preferences. Indeed, our results cannot be seen as finding strong and widespread oppositional identities. Nevertheless, our empirical findings do suggest that extreme ethnic preferences for non-whites are related to whether they were married to someone outwith their own community, their fluency in the English language and whether they

\footnotetext{
${ }^{14}$ Car ownership and housing tenure may of course be endogenous in the employment equation (Blackaby et al., 1997). Indeed, employment raises income making it easier to purchase a home and/or a private vehicle, and steady employment in a fixed location may encourage home-ownership relative to other forms of tenure.

${ }^{15}$ We also used the whole set of responses for each of the four identity variables to construct four ordered oppositional identity variables and one aggregate ordered oppositional variable and then ran a set of ordered probits. On the whole the results were slightly weaker but did still point to the importance of being UK born, years since migration, ethnic enclaves and intermarriage. The instruments were slightly weaker. Where we included in the employment model the ordered oppositional identity variables we again found that a higher Nbrit and Smind reduces the probability of being in employment.
} 
born in and how long they have been resident in the UK. In addition, we find that a belief in single faith schools, an experience of racial harassment and having had an arranged marriage are all associated with more extreme preferences.

Though one needs to be cautious in this type of analysis, our results do also suggest that there is an employment penalty associated with extreme identities. Those with extreme preferences experience a 6 to $7 \%$ lower probability of being in employment relative to those with less extreme views. These effects are evident when we control for the endogeneity of ethnic preferences and a range of variables capturing assimilation effects. Though the size of these effects is non-trivial, the effects are smaller than the influence of other variables such as domestic educational qualifications, inter-ethnic marriage and home and car-ownership. On the other hand, the size of the effects are larger than the effects of other variables which have received much more attention in the literature on ethnic disadvantage (i.e. language fluency and ethnic enclaves).

As it stands, our results are broadly in line with the very small number of empirical studies in this area. Nekby and Rödin (2007) and Constant and Zimmerman (2008) for Sweden and Germany respectively, find that "separated" males (identify with origin country and not with host country) have a lower probability of working relative to those who are assimilated (identify with host country and not origin country). Similarly, a Canadian study by Pendakur and Pendakur (2004) finds that for "visible" minorities ethnic identity is associated with lower job quality. The only study, as far as we aware, that finds no effect is by Casey and Dustmann (2009). Using German panel data they find no correlation between ethnic identity and various labour market outcomes including wages, participation, employment and unemployment. Despite the evidence for an identity effect on economic outcomes, the research is embryonic and further research is clearly needed on the relationship between cultural and ethnic identity and success in the labour market. This requires not only more purpose built data but also more theoretical explorations trying to delineate the mechanisms through which ethnic identity may impact on economic outcomes and behaviour.

\section{References}

[1] Akerlof, G.A. (1997), 'Social distance and social decisions.' Econometrica, vol.65, (September), pp.1005-27.

[2] Akerlof, G.A. and Kranton, R.E. (2000), 'Economics and identity.' Quarterly Journal of Economics, vol.115, (August), pp.715-53.

[3] Akerlof, G.A. and Kranton, R.E. (2002), 'Identity and schooling: Some lessons for the economics of education.' Journal of Economic Literature, vol.40, (December), pp.1167-1201. 
[4] Alesina, A. and La Ferrara, E. (2001). 'Who trusts others?' Journal of Public Economics, vol.85, (August), pp.207-34.

[5] Austen-Smith D. and Fryer, Jr, R.D. (2005). 'An economic analysis of 'acting white'.' Quarterly Journal of Economics, vol.120, (May), pp.551-83.

[6] Battu, H. McDonald, M. and Zenou, Y. (2007). 'Oppositional identities and the labor market.' Journal of Population Economics, vol.20, (July), pp.643-67.

[7] Berthoud, R. (2000). 'Ethnic employment penalties in Britain.' Journal of Ethnic and Migration Studies, vol.26, (July), 389-416.

[8] Bisin, A., Patacchini, E., Verdier, T. and Zenou, Y. (2008a). 'Formation and persistence of oppositional identities.' Unpublished manuscript, Stockholm University.

[9] Bisin, A., Patacchini, E., Verdier, T. and Zenou, Y. (2008b). 'Are Muslim immigrants different in terms of cultural integration?' Journal of the European Economic Association, vol.6, (AprilMay), pp.445-56.

[10] Blackaby, D. Drinkwater, S. Leslie, D. and Murphy, P. (1997). 'A picture of male and female unemployment among Britain's ethnic minorities.' Scottish Journal of Political Economy, vol.44, (May), pp.182-97.

[11] Blackaby, D. Leslie, D. Murphy, P. and O'Leary, N. (1999). 'Unemployment among Britain's ethnic minorities.' The Manchester School, vol.67, (January), pp.1-20.

[12] Borjas, G.J. (1994). 'The economics of immigration.' Journal of Economic Literature, vol.32, (December), pp.1667-1717.

[13] Brown, M.S. (2000). 'Religion and economic activity in the South Asian population.' Ethnic and Racial Studies, vol.23, (November), 1035-61.

[14] Building Cohesive Communities (2001). A Report of the Ministerial Group on Public Order and Community Cohesion, London: HMSO.

[15] Calvó-Armengol, A. and Jackson, M. (2004). 'The effects of social networks on employment and inequality.' American Economic Review, vol.94, (June), pp.426-54.

[16] Calvó-Armengol, A. and Zenou, Y. (2005). 'Job matching, social network and word-of-mouth communication.' Journal of Urban Economics, vol.57, (May), pp.500-22.

[17] Cantle Report (2001). Community Cohesion, London: HMSO. 
[18] Casey, T. and Dustmann, C. (2009). 'Immigrants' identity, economic outcomes, and the transmission of identity across generations.' ECONOMIC JOURNAL, this issue.

[19] Chiswick, B.R. (1978). 'The effect of Americanization on earnings of foreign born men.' Journal of Political Economy, vol.86, (October), pp.897-921.

[20] Constant, A.F. and Zimmermann, K.F. (2008). 'Measuring ethnic identity and its impact on economic behavior.' Journal of the European Economic Association, vol.6, (April-May), pp.424-33.

[21] Cornell, B. and Welch, I. (1996). 'Culture, information, and screening discrimination.' Journal of Political Economy, vol.104, (June), pp.542-71.

[22] CRE (2002). Report on Racial Segregation in the North of England.

[23] Cutler, D. M. and Glaeser, E.L. (1997). 'Are ghettos good or bad?' Quarterly Journal of Economics, vol.112, (August), pp.827-72.

[24] Delpit, L. (1995). Other People's Children: Cultural Conflict in the Classroom, New York: The Free Press.

[25] DETR (2000). Survey of English Housing, London: HMSO.

[26] Dustmann, C. and Fabbri, F. (2003). 'Language proficiency and labour market performance of immigrants in the UK.' ECONOMIC JOURNAL, vol.113, (July), pp.695-717.

[27] Edin, P-A., Fredriksson, P. and Åslund, O. (2003). 'Ethnic enclaves and the economic success of immigrants. Evidence from a natural experiment.' Quarterly Journal of Economics, vol.118, (February), pp.329-57.

[28] Ethnic Minorites' Economic Performance (2001), PIU, London: Cabinet Office.

[29] Fordham, S. and Ogbu, J.U. (1986). 'Black student'school success: Coping with the burden of 'acting white'.' The Urban Review, vol.18, (September), pp.176-206.

[30] Friedberg, R.M. (2000). 'You can't take it with you? Immigrant assimilation and the portability of human capital.' Journal of Labor Economics, vol.18, (April), pp.221-51.

[31] Fryer, R.G. Jr. and Torelli, P. (2005). 'An empirical analysis of 'acting white'.' NBER Working Paper No. 11334.

[32] Hai, Y. (2008), The Making of Mr Hai's Daughter: Becoming British, London: Virago Press. 
[33] Heath, A. (2001). Ethnic Minorities in the Labour Market (Future Research). Report to the PIU, Cabinet Office, October 2001.

[34] Hughes, G.A. and McCormick, B. (1987). 'Housing markets, unemployment and labour market flexibility in the UK.' European Economic Review, vol.31, (April), pp.615-45.

[35] Iannaccone, L.R. (1998). 'Introduction to the economics of religion.' Journal of Economic Literature, vol.36, (September), pp.1465-96.

[36] Ioannides, Y.M. and Loury, L.D. (2004). 'Job information networks, neighborhood effects, and inequality.' Journal of Economic Literature, vol.42, (December), pp.1056-93.

[37] Ihlanfeldt, K.R. and Scafidi, B. (2002). 'Black self-segregation as a cause of housing segregation. Evidence from the multi-city study of urban inequality.' Journal of Urban Economics, vol.51, (March), pp.366-90.

[38] Lang, K. (1986). 'A language theory of discrimination," Quarterly Journal of Economics, vol.101, (May), pp.363-82.

[39] Lazear, E.P. (1999). 'Culture and language.' Journal of Political Economy, vol.107, (December), pp.S95-S126.

[40] Leslie, D. and Drinkwater, S. (1999). 'Staying on in full-time education: Reasons for higher participation among ethnic minority males and females.' Economica, vol.66, (February), pp.6377.

[41] Mason, P.L. (2004). 'Annual income, hourly wages, and identity among Mexican-Americans and other Latinos.' Industrial Relations, vol.43, (October), pp.817-34

[42] McManus, W.S., Gould, W. and Welch, F. (1983). 'Earnings of hispanic men: The role of English language proficiency.' Journal of Labor Economics, vol.1, (April), pp.101-130.

[43] Meng, X. and Gregory, R.G. (2005). 'Intermarriage and the economic assimilation of immigrants.' Journal of Labor Economics, vol.23, (January), pp.135-75.

[44] Modood, T. et al. (1997), Ethnic Minorities in Britain: Diversity and Disadvantage, London: Policy Studies Institute.

[45] Montgomery, J. (1991). 'Social networks and labor-market outcomes: Toward an economic analysis.' American Economic Review, vol.81, (December), pp.1408-18. 
[46] Nekby, L. and Rödin, M. (2007). 'Acculturation identity and labor market outcomes,' Unpublished manuscript, Stockholm University.

[47] Ogbu, J.U. (1997). 'Beyond language: ebonics, proper English and identity in a Black American speech community.' Unpublished manuscript, University of California at Berkeley.

[48] Ogbu, J.U. (1978). Minority Education and Caste, New York: Academic Press.

[49] Owen, D. and Green, A.E. (2000). 'Estimating commuting flows for minority groups in England and Wales,' Journal of Ethnic and Migration Studies, vol.26, (October), pp.581-608.

[50] Pagnini, D.L. and Morgan, S.P. (1990). 'Intermarriage and social distance among U.S. immigrants at the turn of the century,' American Journal of Sociology, vol.96, (September), pp.405-32.

[51] Patacchini, E. and Zenou, Y. (2005). 'Spatial mismatch, transport mode and search decisions in England,' Journal of Urban Economics, vol.58, (July), pp.62-90.

[52] Patacchini, E. and Zenou, Y. (2006). 'Racial identity and education,' CEPR Discussion Paper No. 5607.

[53] Pendakur, K. and Pendakur, R. (2005). 'Ethnic identity and the labour market.' Unpublished manuscript, Simon Fraser University, Canada.

[54] Raphael, S. and Stoll, M.A. (2001). 'Can boosting minority car-ownership rates narrow inter-racial employment gaps?' Brookings-Wharton Papers on Urban Economic Affairs, vol.2, (June), pp.99-145.

[55] Selod, H. and Zenou, Y. (2006). 'City-structure, job search, and labour discrimination. Theory and policy implications.' ECONOMIC JOURNAL, vol.116, (October), pp. 1057-87.

[56] Sen, A. (2000), Other People, British Academy Lecture.

[57] Smith R.J. and Blundell, RW. (1986). 'An exogeneity test for a simultaneous equation tobit model with an application to labor supply,' Econometrica, vol.54, (May), pp.679-86.

[58] Thomas, J.M. (1998). 'Ethnic variation in commuting propensity and unemployment spells: Some UK evidence,' Journal of Urban Economics, vol.43, (May), pp.385-400.

[59] Topa, G. (2001). 'Social interactions, local spillovers and unemployment,' Review of Economic Studies, vol.68, (April), pp.261-295. 
Table 1: Means and standard deviations of selected variables

\begin{tabular}{|c|c|c|c|}
\hline Variable & Mean & $\begin{array}{l}\text { Std. } \\
\text { Dev. }\end{array}$ & Description \\
\hline Emp & 0.776 & 0.417 & Employment status, 1 if employed 0 otherwise (ILO definition) \\
\hline Rharra & 0.131 & 0.338 & 1 if was racially harassed \\
\hline Schrelig & 0.167 & 0.373 & 1 if prefers own religion school for children \\
\hline Arrmar & 0.164 & 0.371 & 1 if had arranged marriage \\
\hline Fluent & 0.726 & 0.446 & 1 if speaks English fluently \\
\hline UKborn & 0.332 & 0.471 & 1 if born in the UK \\
\hline Yrsmg & 21.01 & 9.44 & Years since migration \\
\hline Oethcon & 0.053 & 0.223 & 1 if living in own ethnic concentration area of $33 \%$ or more \\
\hline Marown & 0.673 & 0.469 & 1 if married to someone from own ethnic group \\
\hline Intmar & 0.053 & 0.210 & 1 if married to someone from a different ethnic group \\
\hline Unmar & 0.274 & 0.446 & 1 if single \\
\hline Caribbean & 0.296 & 0.457 & 1 if of Caribbean origin \\
\hline African-Asian & 0.159 & 0.365 & 1 if of African-Asian origin \\
\hline Bangladeshi & 0.056 & 0.229 & 1 if of Bangladeshi origin \\
\hline Pakistani & 0.165 & 0.373 & 1 if of Pakistani origin \\
\hline Indian & 0.278 & 0.428 & 1 if of Indian origin \\
\hline Chinese & 0.046 & 0.265 & 1 if of Chinese origin \\
\hline Age & 33.89 & 11.93 & Age of respondent \\
\hline Male & 0.600 & 0.490 & 1 if male \\
\hline Child04 & 0.407 & 0.491 & Presence of children of age less than 5 \\
\hline Childd511 & 0.508 & 0.500 & Presence of children between 5 and 11 years old \\
\hline Child1215 & 0.328 & 0.469 & Presence of children between 12 and 15 years old \\
\hline Child16ov & 0.370 & 0.483 & Presence of children of 16 years or more \\
\hline UKdegree & 0.118 & 0.323 & 1 if has UK higher degree, degree, Diploma or equivalent \\
\hline UKalevel & 0.149 & 0.406 & 1 if has UK A-Level qualification or equivalent \\
\hline UKolevel & 0.255 & 0.498 & 1 if has UK O-Level qualification or equivalent \\
\hline NUKqual & 0.478 & 0.500 & 1 if has no UK qualifications \\
\hline Fqual & 0.206 & 0.404 & 1 if has any foreign qualifications \\
\hline North & 0.208 & 0.405 & 1 if living in north of England \\
\hline Midlands & 0.287 & 0.452 & 1 if living in the Midlands \\
\hline South & 0.505 & 0.500 & 1 if living in South or South East \\
\hline Owner-occupier & 0.720 & 0.449 & 1 if owner occupier \\
\hline Own car & 0.754 & 0.431 & 1 if owns a car \\
\hline Un04 & 0.082 & 0.274 & Ward unemployment rate less than 5\% \\
\hline Un59 & 0.304 & 0.460 & Ward unemployment rate between 5 \&9\% \\
\hline Un1014 & 0.229 & 0.420 & Ward unemployment rate between $10 \& 14 \%$ \\
\hline Un1519 & 0.143 & 0.350 & Ward unemployment rate between 15 \&19\% \\
\hline Un20m & 0.242 & 0.428 & Ward unemployment rate of $20 \%$ or more \\
\hline
\end{tabular}


Table 2: In many ways I think of myself as British (\%)

\begin{tabular}{lrrrrrr}
\hline & Caribbean & Indian & $\begin{array}{r}\text { African } \\
\text { Asian }\end{array}$ & Pakistani & Bangladeshi & Chinese \\
\hline Strongly agree & 20.09 & 13.98 & 25.79 & 22.53 & 14.23 & 10.00 \\
Agree & 37.77 & 43.69 & 45.28 & 37.55 & 41.90 & 38.00 \\
Neither & 8.30 & 13.40 & 10.69 & 16.21 & 20.55 & 11.00 \\
Disagree & 24.02 & 23.30 & 16.04 & 15.22 & 18.58 & 33.00 \\
Strongly disagree & 9.83 & 5.63 & 2.20 & 8.50 & 4.74 & 8.00 \\
N & 458 & 515 & 318 & 506 & 253 & 100 \\
\hline
\end{tabular}

Table 3: In many ways I think of myself as ....[Respondent's ethnic group] (\%)

\begin{tabular}{lrrrrrr}
\hline & Caribbean & Indian & $\begin{array}{r}\text { African } \\
\text { Asian }\end{array}$ & Pakistani & Bangladeshi & Chinese \\
\hline Strongly agree & 49.89 & 39.81 & 43.71 & 44.36 & 49.61 & 53.00 \\
Agree & 34.06 & 47.57 & 42.14 & 41.78 & 44.09 & 40.00 \\
Neither & 6.50 & 7.18 & 8.80 & 9.70 & 2.75 & 1.00 \\
Disagree & 7.59 & 4.85 & 4.72 & 2.57 & 3.15 & 4.00 \\
Strongly disagree & 1.95 & 0.58 & 0.63 & 1.58 & 0.39 & 2.00 \\
N & 461 & 515 & 318 & 505 & 254 & 100 \\
\hline
\end{tabular}

Table 4: If a close relative were to marry a white person (\%)

\begin{tabular}{lrrrrrr}
\hline & Caribbean & Indian & $\begin{array}{r}\text { African } \\
\text { Asian }\end{array}$ & Pakistani & Bangladeshi & Chinese \\
\hline Would not mind & 82.43 & 51.87 & 66.25 & 38.61 & 49.60 & 84.69 \\
Mind a little & 6.51 & 10.02 & 11.04 & 11.09 & 9.20 & 6.12 \\
Mind very much & 8.24 & 27.89 & 13.56 & 36.83 & 33.20 & 7.14 \\
Can't say & 2.82 & 10.22 & 9.15 & 13.47 & 8.00 & 2.05 \\
N & 461 & 509 & 317 & 505 & 250 & 98 \\
\hline
\end{tabular}

Table 5: How important is ethnicity in choosing a school? (\%)

\begin{tabular}{lrrrrrr}
\hline & Caribbean & Indian & $\begin{array}{r}\text { African } \\
\text { Asian }\end{array}$ & Pakistani & Bangladeshi & Chinese \\
\hline Very important & 15.94 & 6.81 & 8.44 & 12.06 & 16.21 & 3.03 \\
Fairly important & 20.74 & 16.15 & 15.31 & 16.60 & 18.58 & 7.07 \\
Not very important & 16.16 & 13.42 & 10.31 & 15.02 & 16.21 & 15.15 \\
No influence & 44.32 & 57.78 & 59.06 & 47.23 & 38.34 & 73.74 \\
Can’t say & 2.84 & 5.84 & 6.88 & 9.09 & 10.67 & 1.01 \\
N & 458 & 514 & 320 & 506 & 253 & 99 \\
\hline
\end{tabular}

Table 6: What proportion of one's ethnic group would you like in your children's school? (\%)

\begin{tabular}{lrrrrrr}
\hline & Caribbean & Indian & $\begin{array}{r}\text { African } \\
\text { Asian }\end{array}$ & Pakistani & Bangladeshi & Chinese \\
\hline Fewer than half & 16.67 & 11.07 & 14.42 & 9.49 & 14.17 & 23.23 \\
About half & 35.06 & 18.83 & 20.06 & 28.06 & 30.31 & 7.07 \\
More than half & 4.11 & 1.55 & 1.57 & 5.14 & 5.12 & 1.01 \\
No preference & 40.69 & 63.11 & 56.11 & 48.62 & 40.94 & 68.69 \\
Can't say & 3.46 & 5.44 & 7.84 & 8.70 & 9.45 & 0.00 \\
$\mathrm{~N}$ & 462 & 515 & 319 & 506 & 254 & 99 \\
\hline
\end{tabular}


Table 7: Oppositional identity variables

\begin{tabular}{|c|c|c|c|}
\hline Variable & Description & Mean & Std. Dev. \\
\hline Nbrit & $\begin{array}{l}1 \text { if strongly disagree that in many ways I think of myself } \\
\text { as British, } 0 \text { if neither agree or disagree, agree, disagree, } \\
\text { strongly agree and can't say. }\end{array}$ & 0.067 & 0.250 \\
\hline Oethnic & $\begin{array}{l}1 \text { if strongly agree that in many ways I think of myself as } \\
\text { being of the original ethnic group (e.g. Indian, Pakistani } \\
\text { etc), } 0 \text { if neither agree nor disagree, agree, disagree, } \\
\text { strongly disagree and can't say. }\end{array}$ & 0.456 & 0.498 \\
\hline Smind & $\begin{array}{l}1 \text { if mind very much if a relative marries a white person, } \\
0 \text { if does not mind, mind very little and can't say. }\end{array}$ & 0.190 & 0.392 \\
\hline Schcon & $\begin{array}{l}1 \text { if prefers school for children with half or more of the } \\
\text { pupils being from his or her own ethnic group. }\end{array}$ & 0.288 & 0.453 \\
\hline Opid & $\begin{array}{l}1 \text { if extremely oppositional (at least two of nbrit, oethnic, } \\
\text { smind or schch equal to one), } 0 \text { otherwise }\end{array}$ & 0.0867 & 0.2815 \\
\hline
\end{tabular}


Table 8: Non-white identities - probit regressions (first stage)

\begin{tabular}{|c|c|c|c|c|c|}
\hline & Nbrit & Oethnic & Smind & Schcon & Opid \\
\hline \multirow[t]{2}{*}{ Rharra } & 0.046 & 0.006 & 0.122 & 0.060 & 0.056 \\
\hline & $(2.37)^{*}$ & $(0.12)$ & $(2.46)^{*}$ & $(1.76)^{+}$ & $(1.81)^{+}$ \\
\hline \multirow[t]{2}{*}{ Schrelig } & 0.031 & 0.142 & 0.217 & 0.116 & 0.115 \\
\hline & $(2.28)^{*}$ & $(3.50)^{* *}$ & $(5.74)^{* *}$ & $(3.22)^{* *}$ & $(5.28)^{* *}$ \\
\hline \multirow[t]{2}{*}{ Arrmar } & 0.045 & 0.004 & 0.155 & 0.046 & 0.052 \\
\hline & $(2.93)^{* *}$ & $(0.10)$ & $(4.49) * *$ & (1.27) & $(2.53)^{*}$ \\
\hline \multirow[t]{2}{*}{ Fluent } & -0.026 & -0.135 & -0.093 & -0.009 & -0.027 \\
\hline & $(1.82)^{+}$ & $(2.92)^{* *}$ & $(2.20)^{*}$ & $(0.22)$ & $(1.98)^{*}$ \\
\hline \multirow[t]{2}{*}{ UKborn } & -0.048 & -0.355 & -0.084 & -0.103 & -0.084 \\
\hline & $(3.30)^{* *}$ & $(4.80)^{* *}$ & (1.16) & (1.57) & $(3.30)^{* *}$ \\
\hline \multirow[t]{2}{*}{ Yrsmg } & -0.003 & -0.007 & -0.012 & -0.021 & -0.003 \\
\hline & $(4.02)^{* *}$ & $(2.72)^{* *}$ & $(0.09)$ & $(0.67)$ & $(2.21)^{*}$ \\
\hline \multirow[t]{2}{*}{ Oethcon } & 0.041 & 0.128 & 0.039 & 0.014 & 0.027 \\
\hline & $(2.44)^{*}$ & $(2.36)^{*}$ & $(0.87)$ & $(0.30)$ & (1.11) \\
\hline \multirow[t]{2}{*}{ Marown } & -0.010 & -0.054 & -0.075 & -0.006 & -0.020 \\
\hline & $(0.58)$ & $(0.94)$ & (1.41) & $(0.11)$ & $(0.70)$ \\
\hline \multirow[t]{2}{*}{ Intmar } & -0.036 & -0.067 & -0.253 & -0.097 & -0.084 \\
\hline & $(1.79)+$ & $(0.76)$ & $(3.63)^{* *}$ & (1.30) & $(2.31)^{*}$ \\
\hline \multirow[t]{2}{*}{ Caribbean } & 0.098 & 0.061 & -0.224 & 0.177 & 0.001 \\
\hline & $(2.70)^{* *}$ & $(0.98)$ & $(4.60)^{* *}$ & $(2.98)^{* *}$ & $(0.02)$ \\
\hline \multirow[t]{2}{*}{ African-Asian } & -0.044 & -0.094 & -0.145 & 0.060 & -0.049 \\
\hline & $(2.02)^{*}$ & $(1.78)+$ & $(3.33)^{* *}$ & (1.15) & $(1.97)^{*}$ \\
\hline \multirow[t]{2}{*}{ Bangladeshi/Pakistani } & -0.004 & -0.000 & -0.074 & 0.102 & 0.003 \\
\hline & $(0.33)$ & $(0.01)$ & $(1.96)+$ & $(2.49)^{*}$ & $(0.16)$ \\
\hline Age & -0.000 & 0.013 & -0.010 & -0.007 & -0.011 \\
\hline & $(0.08)$ & $(0.93)$ & $(0.76)$ & $(0.54)$ & $(1.65)+$ \\
\hline Age2/100 & 0.002 & -0.009 & 0.015 & 0.005 & 0.014 \\
\hline & $(0.27)$ & $(0.53)$ & (1.05) & $(0.36)$ & $(1.76)^{+}$ \\
\hline Male & -0.017 & -0.027 & -0.021 & 0.025 & -0.012 \\
\hline & (1.43) & $(0.73)$ & $(0.63)$ & $(0.78)$ & $(0.61)$ \\
\hline Child04 & -0.022 & 0.005 & 0.018 & 0.037 & -0.027 \\
\hline & $(1.56)$ & $(0.13)$ & $(0.51)$ & $(1.05)$ & (1.37) \\
\hline Child511 & 0.011 & -0.042 & 0.060 & 0.004 & 0.029 \\
\hline & $(0.88)$ & (1.17) & $(1.90)+$ & $(0.13)$ & $(1.68)+$ \\
\hline Child1215 & 0.001 & -0.037 & 0.009 & 0.030 & 0.026 \\
\hline & $(0.12)$ & $(0.97)$ & $(0.27)$ & (0.89) & (1.34) \\
\hline UKdegree & -0.017 & -0.079 & -0.097 & 0.160 & 0.004 \\
\hline & $(0.92)$ & (1.17) & (1.48) & $(2.42)^{*}$ & $(0.10)$ \\
\hline UKalevel & -0.031 & -0.019 & 0.164 & 0.016 & 0.011 \\
\hline & $(1.71)^{+}$ & $(0.30)$ & $(2.45)^{*}$ & $(0.26)$ & $(0.28)$ \\
\hline UKolevel & -0.025 & 0.023 & -0.001 & 0.027 & -0.032 \\
\hline & (1.54) & $(0.41)$ & $(0.02)$ & $(0.56)$ & (1.19) \\
\hline Fqual & 0.008 & -0.115 & -0.061 & -0.024 & -0.026 \\
\hline & (0.59) & $(2.92)^{* *}$ & $(1.80)+$ & $(0.67)$ & (1.45) \\
\hline North & 0.030 & 0.195 & 0.092 & 0.013 & 0.060 \\
\hline & (1.60) & $(3.94)^{* *}$ & $(2.02)^{*}$ & $(0.29)$ & $(2.13)^{*}$ \\
\hline Midlands & 0.027 & 0.048 & 0.034 & 0.042 & 0.036 \\
\hline & $(1.85)^{+}$ & $(1.21)$ & $(0.95)$ & $(1.20)$ & $(1.69)+$ \\
\hline Owner-occupier & -0.036 & -0.048 & 0.005 & -0.081 & -0.030 \\
\hline & $(2.52)^{*}$ & (1.14) & $(0.12)$ & $(2.26)^{*}$ & (1.48) \\
\hline Own car & 0.020 & 0.052 & -0.003 & -0.060 & -0.006 \\
\hline & $(1.72)^{+}$ & $(1.22)$ & $(0.08)$ & $(1.69)+$ & $(0.28)$ \\
\hline Un59 & 0.008 & -0.168 & 0.182 & -0.011 & 0.011 \\
\hline & $(0.18)$ & (1.63) & $(2.26)^{*}$ & $(0.10)$ & $(0.14)$ \\
\hline Un1014 & 0.061 & 0.100 & 0.113 & 0.134 & 0.057 \\
\hline & $(1.20)$ & $(0.95)$ & $(1.30)$ & (1.19) & $(0.66)$ \\
\hline Un1519 & 0.033 & 0.184 & 0.108 & 0.037 & 0.012 \\
\hline & $(0.66)$ & $(1.73)^{+}$ & $(1.22)$ & $(0.33)$ & $(0.17)$ \\
\hline Un20m & 0.034 & 0.137 & 0.161 & 0.122 & 0.007 \\
\hline & $(0.75)$ & $(1.28)$ & $(1.78)+$ & $(1.09)$ & $(0.10)$ \\
\hline Observations & 942 & 1056 & 1057 & 1055 & 991 \\
\hline Pseudo $\mathrm{R}^{2}$ & 0.2044 & 0.1609 & 0.1940 & 0.1665 & 0.1818 \\
\hline Unrestricted Log likelihood $(\varphi)$ & -206.27 & -686.60 & -521.01 & -578.69 & -280.94 \\
\hline Wald $\chi^{2}(\mathrm{~m})$ & 88.66 & 80.42 & 212.20 & 93.50 & 114.44 \\
\hline Prob $>\chi^{2}$ & 0.0000 & 0.0000 & 0.0000 & 0.0000 & 0.0000 \\
\hline Restricted Log likelihood $(\theta)$ & -272.15 & -815.04 & -630.55 & -685.84 & -357.62 \\
\hline LR test $\chi^{2}(3)$ & 131.76 & 256.88 & 219.08 & 214.30 & 153.36 \\
\hline
\end{tabular}


Table 9: Employment - probit regressions (Second Stage)(correcting for endogeneity)

\begin{tabular}{|c|c|c|c|c|c|}
\hline & (1) & $(2)$ & (3) & (4) & (5) \\
\hline Nbrit & $\begin{array}{c}-0.070 \\
(1.89)+\end{array}$ & & & & \\
\hline Oethnic & & $\begin{array}{l}-0.065 \\
(1.26)\end{array}$ & & & \\
\hline Smind & & & $\begin{array}{c}-0.064 \\
(2.02)^{*}\end{array}$ & & \\
\hline Schcon & & & & $\begin{array}{l}-0.049 \\
(1.36)\end{array}$ & \\
\hline Opid & & & & & $\begin{array}{c}-0.058 \\
(1.99)^{*}\end{array}$ \\
\hline Fluent & $\begin{array}{c}0.084 \\
(1.67)^{+}\end{array}$ & $\begin{array}{c}0.081 \\
(1.86)^{+}\end{array}$ & $\begin{array}{c}0.077 \\
(2.42)^{*}\end{array}$ & $\begin{array}{c}0.079 \\
(2.40)^{*}\end{array}$ & $\begin{array}{c}0.084 \\
(2.39)^{*}\end{array}$ \\
\hline UKborn & $\begin{array}{c}-0.228 \\
(2.44)^{*}\end{array}$ & $\begin{array}{c}-0.234 \\
(1.92)+\end{array}$ & $\begin{array}{l}-0.245 \\
(2.17)^{*}\end{array}$ & $\begin{array}{l}-0.237 \\
(2.04)^{*}\end{array}$ & $\begin{array}{c}-0.223 \\
(2.29)^{*}\end{array}$ \\
\hline Yrsmg & $\begin{array}{c}0.012 \\
(2.73)^{* *}\end{array}$ & $\begin{array}{c}0.009 \\
(2.31)^{*}\end{array}$ & $\begin{array}{c}0.007 \\
(2.40)^{*}\end{array}$ & $\begin{array}{c}0.007 \\
(2.33)^{*}\end{array}$ & $\begin{array}{c}0.009 \\
(2.64)^{* *}\end{array}$ \\
\hline Oethcon & $\begin{array}{c}-0.050 \\
(1.90)^{+}\end{array}$ & $\begin{array}{l}-0.059 \\
(1.57)\end{array}$ & $\begin{array}{l}-0.072 \\
(1.12)\end{array}$ & $\begin{array}{c}-0.059 \\
(0.92)\end{array}$ & $\begin{array}{c}-0.076 \\
(1.19)\end{array}$ \\
\hline Marown & $\begin{array}{l}0.109 \\
(1.14)\end{array}$ & $\begin{array}{l}0.129 \\
(0.96)\end{array}$ & $\begin{array}{c}0.147 \\
(1.94)+\end{array}$ & $\begin{array}{c}0.136 \\
(1.76)+\end{array}$ & $\begin{array}{c}0.130 \\
(1.72)^{+}\end{array}$ \\
\hline Intmar & $\begin{array}{l}0.170 \\
(1.43)\end{array}$ & $\begin{array}{l}0.183 \\
(1.50)\end{array}$ & $\begin{array}{c}0.197 \\
(1.91)^{+}\end{array}$ & $\begin{array}{c}0.196 \\
(1.79)+\end{array}$ & $\begin{array}{c}0.201 \\
(2.01)^{*}\end{array}$ \\
\hline Caribbean & $\begin{array}{l}-0.051 \\
(0.24)\end{array}$ & $\begin{array}{l}-0.053 \\
(0.34)\end{array}$ & $\begin{array}{c}-0.061 \\
(1.90)+\end{array}$ & $\begin{array}{c}-0.052 \\
(0.36)\end{array}$ & $\begin{array}{c}-0.053 \\
(1.31)\end{array}$ \\
\hline African-Asian & $\begin{array}{l}0.010 \\
(0.12)\end{array}$ & $\begin{array}{l}0.045 \\
(0.56)\end{array}$ & $\begin{array}{l}0.006 \\
(0.07)\end{array}$ & $\begin{array}{l}0.082 \\
(1.14)\end{array}$ & $\begin{array}{l}0.038 \\
(0.51)\end{array}$ \\
\hline Bangladeshi/Pakistani & $\begin{array}{c}-0.254 \\
(4.33)^{* *}\end{array}$ & $\begin{array}{c}-0.266 \\
(4.47)^{* *}\end{array}$ & $\begin{array}{c}-0.251 \\
(5.33)^{* *}\end{array}$ & $\begin{array}{c}-0.236 \\
(3.87)^{* *}\end{array}$ & $\begin{array}{c}-0.254 \\
(4.62)^{* *}\end{array}$ \\
\hline Age & $\begin{array}{c}0.066 \\
(3.79)^{* *}\end{array}$ & $\begin{array}{c}0.058 \\
(3.41)^{* *}\end{array}$ & $\begin{array}{c}0.055 \\
(3.45)^{* *}\end{array}$ & $\begin{array}{c}0.050 \\
(3.03)^{* *}\end{array}$ & $\begin{array}{c}0.052 \\
(3.30)^{* *}\end{array}$ \\
\hline Age2/100 & $\begin{array}{c}-0.074 \\
(3.70)^{* *}\end{array}$ & $\begin{array}{c}-0.065 \\
(3.25)^{* *}\end{array}$ & $\begin{array}{c}-0.062 \\
(3.33)^{* *}\end{array}$ & $\begin{array}{c}-0.060 \\
(3.10)^{* *}\end{array}$ & $\begin{array}{c}-0.060 \\
(3.20)^{* *}\end{array}$ \\
\hline Male & $\begin{array}{r}-0.071 \\
(1.14)\end{array}$ & $\begin{array}{c}-0.063 \\
(0.52)\end{array}$ & $\begin{array}{c}-0.060 \\
(1.01)\end{array}$ & $\begin{array}{c}-0.064 \\
(0.75)\end{array}$ & $\begin{array}{c}-0.059 \\
(1.00)\end{array}$ \\
\hline Child04 & $\begin{array}{l}-0.000 \\
(0.01)\end{array}$ & $\begin{array}{l}0.022 \\
(0.43)\end{array}$ & $\begin{array}{l}0.034 \\
(0.72)\end{array}$ & $\begin{array}{l}0.034 \\
(0.69)\end{array}$ & $\begin{array}{l}0.012 \\
(0.27)\end{array}$ \\
\hline Child511 & $\begin{array}{c}-0.099 \\
(2.20)^{*}\end{array}$ & $\begin{array}{c}-0.112 \\
(2.75)^{* *}\end{array}$ & $\begin{array}{l}-0.090 \\
(2.05)^{*}\end{array}$ & $\begin{array}{c}-0.116 \\
(2.75)^{* *}\end{array}$ & $\begin{array}{l}-0.098 \\
(2.31)^{*}\end{array}$ \\
\hline Child1215 & $\begin{array}{l}-0.107 \\
(2.25)^{*}\end{array}$ & $\begin{array}{c}-0.104 \\
(2.14)^{*}\end{array}$ & $\begin{array}{c}-0.092 \\
(2.03)^{*}\end{array}$ & $\begin{array}{r}-0.098 \\
(1.61)\end{array}$ & $\begin{array}{c}-0.089 \\
(1.98)^{*}\end{array}$ \\
\hline UKdegree & $\begin{array}{c}0.225 \\
(2.67)^{* *}\end{array}$ & $\begin{array}{c}0.221 \\
(2.44)^{*}\end{array}$ & $\begin{array}{c}0.234 \\
(2.90)^{* *}\end{array}$ & $\begin{array}{c}0.253 \\
(3.24)^{* *}\end{array}$ & $\begin{array}{c}0.238 \\
(3.05)^{* *}\end{array}$ \\
\hline UKalevel & $\begin{array}{l}0.097 \\
(0.90)\end{array}$ & $\begin{array}{l}0.090 \\
(1.05)\end{array}$ & $\begin{array}{l}0.109 \\
(1.37)\end{array}$ & $\begin{array}{l}0.110 \\
(1.38)\end{array}$ & $\begin{array}{l}0.097 \\
(1.23)\end{array}$ \\
\hline UKolevel & $\begin{array}{l}0.042 \\
(0.51)\end{array}$ & $\begin{array}{l}0.029 \\
(0.42)\end{array}$ & $\begin{array}{l}0.026 \\
(0.40)\end{array}$ & $\begin{array}{l}0.040 \\
(0.62)\end{array}$ & $\begin{array}{l}0.029 \\
(0.29)\end{array}$ \\
\hline Fqual & $\begin{array}{l}0.038 \\
(0.77)\end{array}$ & $\begin{array}{l}0.002 \\
(0.04)\end{array}$ & $\begin{array}{l}0.015 \\
(0.30)\end{array}$ & $\begin{array}{l}0.018 \\
(0.37)\end{array}$ & $\begin{array}{l}0.020 \\
(0.42)\end{array}$ \\
\hline North & $\begin{array}{c}0.111 \\
(2.60)^{* *}\end{array}$ & $\begin{array}{c}0.114 \\
(2.16)^{*}\end{array}$ & $\begin{array}{c}0.119 \\
(2.75)^{* *}\end{array}$ & $\begin{array}{c}0.113 \\
(2.18)^{*}\end{array}$ & $\begin{array}{c}0.117 \\
(2.69)^{* *}\end{array}$ \\
\hline Midlands & $\begin{array}{c}0.117 \\
(2.80)^{* *}\end{array}$ & $\begin{array}{c}0.114 \\
(2.43)^{*}\end{array}$ & $\begin{array}{c}0.117 \\
(2.58)^{* *}\end{array}$ & $\begin{array}{c}0.114 \\
(2.53)^{*}\end{array}$ & $\begin{array}{c}0.126 \\
(2.73)^{* *}\end{array}$ \\
\hline Owner-occupier & $\begin{array}{c}0.128 \\
(2.41)^{*}\end{array}$ & $\begin{array}{c}0.139 \\
(3.07)^{* *}\end{array}$ & $\begin{array}{c}0.125 \\
(2.36)^{*}\end{array}$ & $\begin{array}{c}0.141 \\
(3.24)^{* *}\end{array}$ & $\begin{array}{c}0.122 \\
(2.51)^{*}\end{array}$ \\
\hline Own car & $\begin{array}{c}0.088 \\
(1.77)^{+}\end{array}$ & $\begin{array}{l}0.081 \\
(1.53)\end{array}$ & $\begin{array}{c}0.087 \\
(1.84)^{+}\end{array}$ & $\begin{array}{c}0.094 \\
(1.97)^{*}\end{array}$ & $\begin{array}{l}0.079 \\
(1.61)\end{array}$ \\
\hline Un59 & $\begin{array}{c}-0.055 \\
(0.74)\end{array}$ & $\begin{array}{l}-0.049 \\
(0.22)\end{array}$ & $\begin{array}{l}-0.057 \\
(0.34)\end{array}$ & $\begin{array}{r}-0.052 \\
(0.74)\end{array}$ & $\begin{array}{l}-0.058 \\
(0.69)\end{array}$ \\
\hline Un1014 & $\begin{array}{l}-0.041 \\
(0.23)\end{array}$ & $\begin{array}{l}-0.052 \\
(0.29)\end{array}$ & $\begin{array}{l}-0.048 \\
(0.28)\end{array}$ & $\begin{array}{l}-0.031 \\
(0.18)\end{array}$ & $\begin{array}{l}-0.016 \\
(0.10)\end{array}$ \\
\hline Un1519 & $\begin{array}{l}-0.059 \\
(0.34)\end{array}$ & $\begin{array}{l}-0.042 \\
(0.12)\end{array}$ & $\begin{array}{l}-0.047 \\
(0.10)\end{array}$ & $\begin{array}{l}-0.055 \\
(0.46)\end{array}$ & $\begin{array}{l}-0.045 \\
(0.27)\end{array}$ \\
\hline Un20m & $\begin{array}{l}-0.096 \\
(0.20)\end{array}$ & $\begin{array}{l}-0.118 \\
(0.64)\end{array}$ & $\begin{array}{c}-0.114 \\
(0.66)\end{array}$ & $\begin{array}{l}-0.097 \\
(0.04)\end{array}$ & $\begin{array}{c}-0.099 \\
(0.30)\end{array}$ \\
\hline Observations & 705 & 706 & 706 & 704 & 703 \\
\hline Pseudo $\mathrm{R}^{2}$ & 0.2103 & 0.2083 & 0.2110 & 0.2065 & 0.2074 \\
\hline Log likelihood & -348.03 & -349.83 & -348.62 & -349.40 & -348.11 \\
\hline Wald $\chi^{2}(\mathrm{~m})$ & 185.39 & 184.08 & 186.51 & 181.89 & 182.18 \\
\hline Prob $>\chi^{2}$ & 0.0000 & 0.0000 & 0.0000 & 0.0000 & 0.0000 \\
\hline
\end{tabular}

Absolute value of z-statistics in parentheses, + significant at $10 \%$; significant at $5 \%$; ** significant at $1 \%$. 